\title{
Studies on the Fungicidal Action of Dithiocarbamates 3. Effect of sodium dimethyldithiocarbamate on the fatty acid synthesis of Xanthomonas oryzae
}

\author{
Katsuyoshi Yoneyama,* Shigeko Sekido* and Tomomasa Misato* \\ 米山勝美*・関戸茂子* ・見里朝正* : Dithiocarbamate 系殺菌剂の作用機作に関する研究 \\ 3.イネ白葉枯病菌の脂肪酸合成に及ぼす Sodium dimethyldithiocarbamate の作用
}

\begin{abstract}
The previous studies made on the mode of action of sodium dimethyldithiocarbamate(NaDMDC) showed that the compound inhibited the lipid synthesis of Xanthomonas oryzae, but not the process from long-chain fatty acids to phospholipids in the biosynthetic pathway of lipids. Further examinations were made on the effects of NaDMDC on the process from acetate to fatty acid formation. NaDMDC inhibited neither the two kinds of enzymes involving in the formation of acetyl CoA from acetate, acetate kinase and phosphotransacetylase, nor the enzyme concerning in the synthesis of malonyl CoA from acetyl CoA, acetyl CoA carboxylase. However, the compound had a high inhibitory effect on the incorporation of ${ }^{14} \mathrm{C}$-malonyl CoA into fatty acids, in either the fatty acid-synthesizing enzyme system of Escherichia coli or the cellfree extracts of $X$. oryzae.

From these results, it is concluded that NaDMDC inhibits primarily the fatty acid synthesis of $X$. oryzae, and gives a remarkable influence upon the entire lipid biosynthesis.
\end{abstract}

(Received April 17, 1978)

\section{Introduction}

Sodium dimethyldithiocarbamate (NaDMDC) is the simplest compound of dialkylamine series in the dithiocarbamate fungicides. Studies on the fungicidal activity of NaDMDC by many researchers revealed that the toxic mechanism was involved in the inactivation of various enzymes, such as sulfhydryl-containing enzymes $^{16)}$ or coenzymes ${ }^{13)}$, and metal-containing enzymes ${ }^{3,11,12)}$. These studies with fungal cells, however, have been mainly directed to an examination of the effects on the glycolysis or respiration systems, rather than on the macromolecular synthesis of cells. Recently, the authors undertook a detailed investigation of the effects on the metabolism of bacterial cells using Xanthomonas oryzae. The results indicated that NaDMDC had a remarkable inhibitory effect on the synthesis of lipids, but had little effect on the respiration and the syntheses of protein, nucleic acid and cell wall in X. oryzae ${ }^{22}$. Subsequent studies also showed that NaDMDC did not affect either the synthetic process of phospholipids from phosphatidic acid or the transfer step of long-chain fatty acids into phosphatidic acid. On the other

* The Institute of Physical and Chemical Research, Wako, Saitama, Japan. 理化学研究所 
hand, in vivo labeling of phosphatidylethanolamine from ${ }^{14} \mathrm{C}$-glucose was inhibited by NaDMDC much stronger in the fatty acid part than in glycerylphosphorylethanolamine one ${ }^{23)}$. These findings suggested that NaDMDC might affect the synthesis of fatty acids in $X$. oryzae, because the process from long-chain fatty acids to phospholipids in the lipid synthesis was not inhibited by NaDMDC.

The present paper describes conclusive evidence for the inhibitory action of NaDMDC on the metabolism of lipids, especially on the fatty acid synthesis of $X$. oryzae.

\section{Materials and Methods}

Test organisms and chemicals. The culture of Xanthomonas oryzae (strain: H-5809) and Escherichia coli (strain: $\mathrm{K}-12$ ) were used in the experiments. Sodium dimethyldithiocarbamate (NaDMDC) was obtained from the Tokyo Kasei Kogyo. All radioactive compounds were purchased from the Radiochemical Centre, Amersham, except ${ }^{14} \mathrm{C}$-malonyl CoA obtained from the New England Nuclear. Acetate kinase from E. coli, phosphotransacetylase from Clostridium kluyveri, acetylphosphate, CoA and acetyl CoA were purchased from the Boehringer Mannheim, and malonyl CoA from the Sigma Chemical.

Assays of acetate kinase and phosphotransacetylase. The assay system for acetate kinase comprised $0.3 \mathrm{ml}$ of the mixture of $3.2 \mathrm{M}$ potassium acetate, $1.0 \mathrm{M}$ $\mathrm{MgCl}$ and $1.0 \mathrm{M}$ Tris- $\mathrm{HCl}$ buffer $\mathrm{pH} 7.4$ (25:1:5), $0.35 \mathrm{ml}$ of the mixture of $4.0 \mathrm{M} \mathrm{KOH}$ and $28 \%$ hydroxylamine hydrochloride (1:1), $0.1 \mathrm{M} \mathrm{ATP}, 0.2 \mathrm{ml}$ of the aqueous solution of NaDMDC and $0.05 \mathrm{ml}$ of enzyme solution (Protein content: $1.0 \mathrm{mg} / \mathrm{ml}$ ). The assay was carried out by the method of Rose ${ }^{15}$.

The assay system for phosphotransacetylase comprised $0.2 \mathrm{ml} 0.1 \mathrm{M}$ Tris- $\mathrm{HCl}$ buffer $\mathrm{pH} 8.0,0.1 \mathrm{ml}$ of $0.06 \mathrm{M}$ acetylphosphate, $0.1 \mathrm{ml}$ of $0.2 \mathrm{mg} / \mathrm{ml} \mathrm{CoA}, 0.2 \mathrm{ml}$ of the aqueous solution of $\mathrm{NaDMDC}, 0.1 \mathrm{ml}$ of enzyme solution (protein content: $1.0 \mathrm{mg} / \mathrm{ml}$ ) and $0.3 \mathrm{ml}$ of water to make the final volume of $1.0 \mathrm{ml}$. The enzyme assay was performed by the procedure of Stadtman et al. ${ }^{17)}$, and the residual acetylphosphate was determined by the method of Lipmann and Tuttle ${ }^{8)}$.

Assay of acetyl CoA carboxylase. The enzyme of acetyl CoA carboxylase in $E$. coli was prepared by the procedure of Alberts and Vagelos ${ }^{2)}$. The protein precipitate from 25 to $45 \%$ saturation of ammonium sulfate in the cell-free extracts of $E$. coli was dissolved in $0.1 \mathrm{M}$ imidazole- $\mathrm{HCl}$ buffer $\mathrm{pH} 6.7$ to adjust at a concentration of $2 \mathrm{mg} / \mathrm{ml}$ protein content by the Biuret procedure ${ }^{5)}$. This protein solution was used as the crude enzyme of acetyl CoA carboxylase. The assay system consisted of $30 \mu 1$ of $0.1 \mathrm{M}$ imidazole- $\mathrm{HCl}$ buffer $\mathrm{pH} 6.7,10 \mu 1$ each of $4 \mathrm{mM}$ ATP, $3 \mathrm{mM}$ acetyl CoA, 50 ${ }_{\mu} \mathrm{Ci} / \mathrm{ml}{ }^{14} \mathrm{C}$-sodium carbonate $(59.5 \mathrm{mCi} / \mathrm{mmol}), 4 \mathrm{mM} \mathrm{MnCl}_{2}$ and the aqueous solution of NaDMDC, 10 or $20 \mu 1$ of the crude enzyme solution and a small quantity of water to make the final volume of $100 \mu 1$. The reaction was initiated by the addition of ${ }^{14} \mathrm{C}$-sodium carbonate. After incubation at $33^{\circ} \mathrm{C}$ for $10 \mathrm{~min}$, the reaction was stopped by adding $10 \mu \mathrm{l}$ of $2 \mathrm{~N} \mathrm{HCl}$. Subsequently, the incubated mixture was added $0.5 \mathrm{ml}$ of water and centrifuged, and the supernatant solution was transferred in a planchet. After dried under a infrared lamp, the sample was analyzed for radioactivity by a gas flow counter.

Preparation and assay of fatty acid synthase in E. coli. Fatty acid synthase and acyl carrier protein (ACP) from the frozen cells of $E$. coli were prepared according to the method of Goldman et al ${ }^{4)}$. The protein precipitate between 45 and $65 \%$ ammonium sulfate saturation in the cell-free extracts of $E$. coli was dissolved in a minimal volume of $0.05 \mathrm{M}$ Tris- $\mathrm{HCl}$ buffer $\mathrm{pH} 7.5$, and stored at $-20 \mathrm{C}$. Immed- 
iately before use, the protein solution was passed through a Sephadex G-25 column to remove salts. The protein fraction was used as the crude enzyme solution for the synthesis of fatty acids. On the other hand, ACP was prepared from the supernatant of $56 \%$ ammonium sulfate saturation in the above extracts. The supernatant solution was adjusted to $\mathrm{pH} 1.0$ with $5 \mathrm{~N} \mathrm{HCl}$. After centrifugation the precipitate was suspended in a minimal volume of $0.1 \mathrm{M}$ Tris- $\mathrm{HCl}$ buffer $\mathrm{pH} 7.5$ containing $10 \mathrm{mM} 2$ mercaptoethanol by using a glass homogenizer. After the $\mathrm{pH}$ was adjusted to 7.0 with $1 \mathrm{~N} \mathrm{NaOH}$, the ACP-containing solution was treated in boiling water for $5 \mathrm{~min}$. The solution was again centrifuged at $15,000 \times \mathrm{g}$ for $30 \mathrm{~min}$, and the supernatant was used as ACP solution. Protein concentration was determined by the procedure of Lowry $e t a l^{9)}$. The assay of fatty acid synthase was performed by a modification of the method of $\mathrm{Hsu}$ et $a l^{6)}$. The reaction mixture consisted of $50 \mu 1$ of $5 \mathrm{mM}$ NADPH, $25 \mu 1$ of $100 \mu \mathrm{M}$ malonyl CoA, $25 \mu 1$ of $20 \mu \mathrm{M}$ acetyl CoA, $50 \mu 1$ of ACP solution (protein content: $3.5 \mathrm{mg} / \mathrm{ml}$ ), $10 \mu \mathrm{l}$ of $2.5 \mu \mathrm{Ci} / \mathrm{ml}{ }^{14} \mathrm{C}$-malonyl CoA $(20.6$ $\mathrm{mCi} / \mathrm{mmol}$ ), $100 \mu \mathrm{l}$ of the enzyme solution (protein content: $5 \mathrm{mg} / \mathrm{ml}$ ), $100 \mu \mathrm{l}$ of the aqueous solution of NaDMDC and a small volume of water to make the final volume of $0.5 \mathrm{ml}$. The reaction was initiated by the addition of enzyme solution. After incubation at $30^{\circ} \mathrm{C}$ for a given period, the reaction was stopped by the addition of $30 \mu 1$ of $60 \%$ perchloric acid. The incubated mixture was diluted with $0.5 \mathrm{ml}$ of water and $1.0 \mathrm{ml}$ of methanol, then extraction for fatty acids was carried out 2 times with the equivalent volume of petroleum ether. The extracts were transferred into a vial and dried at a room temperature, and the radioactivity was determined by a liquid scintillation counter.

Fatty acid synthesis in the cell-free extracts of $X$. oryzae. $\quad X$. oryzae cells were cultured in Suwa liquid medium ${ }^{18)}$ to obtain logarithmic growth. The cells were collected by centrifugation, and were again suspended in a small volume of $0.01 \mathrm{M}$ phosphate buffer $\mathrm{pH} 7.0$. The suspended cells were ruptured by a French pressure cell. After centrifugation the supernatant was passed through a Sephadex G-25 column, and the protein fraction was used for fatty acid synthesis. The reaction mixture consisted of $100 \mu \mathrm{l}$ of $0.1 \mathrm{M}$ phosphate buffer $\mathrm{pH} 7.0,50 \mu 1$ each of $5 \mathrm{mM}$ NADPH, $20 \mu \mathrm{M}$ acetyl CoA and $0.1 \mathrm{mM}$ malonyl CoA, $100 \mu \mathrm{l}$ of ACP solution (protein content: $3.5 \mathrm{mg} / \mathrm{ml}$ ) from $E$. coli, $20 \mu /$ of $2 \mu \mathrm{Ci} / \mathrm{ml}{ }^{14} \mathrm{C}$-malonyl CoA, 0.2 $\mathrm{ml}$ of the aqueous solution of NaDMDC, $0.2 \mathrm{ml}$ of the cell-free extracts and water to make the final volume of $1.0 \mathrm{ml}$. The reaction was continued at $28^{\circ} \mathrm{C}$ for a given period, and stopped by adding $0.05 \mathrm{ml}$ of $60 \%$ perchloric acid. The incubated mixture was diluted with $1.0 \mathrm{ml}$ of ethanol, and subsequent operation was the same as the procedure for fatty acid synthase of $E$. coli.

\section{Results}

\section{Effect of NaDMDC on the synthesis of acetyl CoA from acetate}

Acetyl CoA synthesis from acetate in bacteria is generally known to depend on 2 kinds of enzymes: one is acetate kinase involving in the formation of acetylphosphate from acetate, the other is phosphotransacetylase in the formation of acetyl CoA from acetylphosphate. The effects of NaDMDC on these enzymes were examined, because the compound inhibited the labeling of the lipids of $X$. oryzae by ${ }^{14} \mathrm{C}$-acetate under in vivo condition as noted previously ${ }^{22}$. Table 1 shows the effect of NaDMDC on acetate kinase activity. In the absence of NaDMDC serving as control systems, the amounts of acetylphosphate produced by the enzyme were $2.6 \mu \mathrm{mol}$ and $6.0 \mu \mathrm{mol}$ in Experiments I and II, respectively. In the presence of NaDMDC, acetylphosphate production was not decreased, but slightly increased in amount as seen in the data 
Table 1. Effect of NaDMDC on acetate kinase

\begin{tabular}{c|c|c|c|c}
\hline \multirow{2}{*}{ Experiments } & \multicolumn{4}{|c}{ Conc. of NaDMDC $(\mu \mathrm{g} / \mathrm{ml})$} \\
\cline { 2 - 5 } & 0 & 1 & 10 & 100 \\
\hline I & 2.6 & 3.5 & 3.6 & 3.7 \\
\hline II & 6.0 & 7.5 & 7.5 & 7.1 \\
\hline
\end{tabular}

Data are expressed as $\mu$ mole in the amounts of acetylphosphate produced.

Table 2. Effect of NaDMDC on phosphotransacetylase

\begin{tabular}{c|c|c|c|c}
\hline \multirow{2}{*}{ Experiments } & \multicolumn{4}{|c}{ Conc. of $\operatorname{NaDMDC}(\mu \mathrm{g} / \mathrm{ml})$} \\
\cline { 2 - 5 } & 0 & 1 & 10 & 100 \\
\hline I & 5.6 & 5.3 & 5.6 & 5.7 \\
\hline II & 4.0 & 5.3 & 5.6 & 5.4 \\
\hline
\end{tabular}

Data are expressed as $\mu$ mole in the amounts of acetyl CoA produced. of either experimental system. The result indicates that NaDMDC has no inhibitory effect on acetate kinase activity. Also, Table 2 shows the effect of NaDMDC on phosphotransacetylase activity. In the control systems of Experiments I and II, the production of acetyl CoA from acetylphosphate by the enzyme was about $5 \mu \mathrm{mol}$ in quantity. In NaDMDC-containing systems, the amount of acetyl CoA production was almost the same as in the control systems, even at a concentration of $100 \mu \mathrm{g} / \mathrm{ml}$ of NaDMDC. The result shows that phosphotransacetylase activity is not affected by NaDMDC. Therefore, it is concluded that NaDMDC does not inhibit the formation of acetyl CoA from acetate.

\section{Effect of NaDMDC on acetyl CoA carboxylase}

Acetyl CoA carboxylase plays an important part in the initial stage of fatty acid synthesis to form malonyl CoA, in which malonyl CoA is produced by the carboxylation of acetyl CoA. An assay of acetyl CoA carboxylase was based on the acetyl CoA-dependent formation of acid-stable radioactivity derived from ${ }^{14} \mathrm{C}$-carbonate.

Table3. Effect of NaDMDC on acetyl CoA carboxylase

\begin{tabular}{c|c|c|c|c}
\hline \multirow{2}{*}{ Experiments } & \multicolumn{4}{|c}{ Conc. of $\mathrm{NaDMDC}(\mu \mathrm{g} / \mathrm{ml})$} \\
\cline { 2 - 5 } & 0 & 1 & 10 & 100 \\
\hline I & 1505 & 1281 & 1731 & 2331 \\
II & 2611 & 2413 & 2912 & 3500 \\
\hline
\end{tabular}

Data are expressed as cpm in the amounts of ${ }^{14} \mathrm{C}-\mathrm{KHCO}_{3}$ incorporated into acid stable products.

Table 3 shows the results of two assay systems with different enzyme amounts: Experiments I and II were $20 \mu \mathrm{g}$ and 40 $\mu \mathrm{g}$ in protein content per reaction mixture, respectively. The radioactivity counts of ${ }^{14} \mathrm{C}$-carbon incorporated into acid-stable products was shown to become higher with increased amount of protein contents. In the presence of NaDMDC, the incorporation of ${ }^{14} \mathrm{C}$-carbonate into acidstable products was not inhibited, but rather stimulated even when the system contained a high concentration of $100 \mu \mathrm{g} / \mathrm{ml}$ of NaDMDC. The result shows that NaDMDC has no inhibitory action on acetyl CoA carboxylase activity.

\section{Effect of NaDMDC on the fatty acid synthesis of E. coli}

Fatty acid synthesis in $E$. coli enzyme system was examined by the incorporation

Table 4. Effect of NaDMDC on fatty acid synthesis in the enzyme system of E. coli

\begin{tabular}{l|c|c|c}
\hline \hline $\begin{array}{c}\text { Conc. of } \\
\text { NaDMDC }\end{array}$ & \multicolumn{3}{|c}{ Incubation time (min) } \\
\cline { 2 - 4 } Control & 412 & 3 & 6 \\
$10 \mu \mathrm{g} / \mathrm{ml}$ & 202 & 5985 & 21001 \\
100 & 98 & 2509 & 6465 \\
\hline
\end{tabular}

Data are expressed as cpm in the amounts of ${ }^{14} \mathrm{C}$-malonyl CoA incorporated into fatty acids. of ${ }^{14} \mathrm{C}$-malonyl CoA into fatty acids. As shown in Table 4 , the radioactivity of ${ }^{14} \mathrm{C}$-malonyl CoA incorporated into fatty acids increased with the lapse of time, and it was about $21,000 \mathrm{cpm}$ at the incubation of 6 min. When NaDMDC was added to the reaction mixture, the incorporation of ${ }^{14} \mathrm{C}$-malonyl $\mathrm{CoA}$ into fatty acids was considerably inhibited at a concentration of $100 \mu \mathrm{g} / \mathrm{ml}$ of NaDMDC, and the inhibition rate was approxi- 
mately $70 \%$. Such a high degree of inhibition by NaDMDC was also observed in the incorporation of ${ }^{14} \mathrm{C}$-acetyl CoA into fatty acids performed with $E$. coli enzyme system, although the data were not shown in this paper. These results suggest that the inhibitory action of NaDMDC is primarily associated with fatty acid synthesis in bacteria.

\section{Characteristics of the cell-free extracts of $X$. oryzae in their fatty acid synthesis}

Cell-free extracts of $X$. oryzae were observed to have an activity for the incorporation of ${ }^{14} \mathrm{C}$-malonyl CoA into fatty acids. To find the best condition for enzyme assay, characteristics of this system for fatty acid synthesis were examined. The results are shown in Table 5 . The complete reaction mixture was made by modifying

Table 5. Characteristics of fatty acid synthesis in the cell-free extracts of $X$. oryzae

\begin{tabular}{l|r|r}
\hline \hline \multicolumn{1}{c}{ Composition } & $\begin{array}{r}\text { Radioactivity } \\
\text { incorporated } \\
(\mathrm{cpm})\end{array}$ & $\begin{array}{r}\text { Rate of 14C-malonyl } \\
\text { CoA incorporation } \\
(\%)\end{array}$ \\
\hline Complete system & 11357 & 100 \\
+2 mM CoA & 16975 & 149 \\
-ACP & 3135 & 28 \\
-ACP +2 mM CoA & 4297 & 38 \\
- Malonyl CoA & 1208 & 11 \\
-Acetyl CoA & 8190 & 72 \\
- NADPH & 467 & 4 \\
-Cell-free extracts & 128 & 1 \\
+1 mM2-mercaptoethanol & 17482 & 154 \\
\hline
\end{tabular}

+ addition to complete system

- removal from complete system the enzyme system for fatty acid synthesis in E. coli. After the omission of each of $\mathrm{ACP}, \mathrm{NADPH}$ and cold malonyl CoA from the mixture, there was little or no activity for the incorporation of ${ }^{14} \mathrm{C}$-malonyl CoA into fatty acids. The replacement of ACP by $\mathrm{CoA}$ in the mixture also caused a great decrease in the rate of ${ }^{14} \mathrm{C}$-malonyl CoA incorporation. On the other hand, the addition of either CoA or 2-mercaptoethanol to the mixture

resulted in an increased incorporation. From these results, each factor of ACP, $\mathrm{NADPH}$ and malonyl CoA seems to be essential for fatty acid synthesis in $X$. oryzae

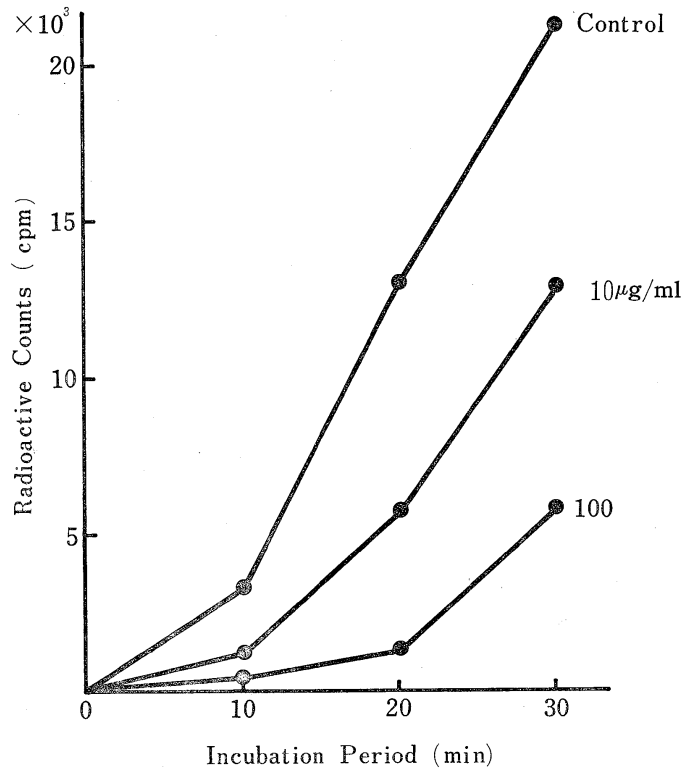

Fig. 1. Effect of NaDMDC on the incorporation of ${ }^{14} \mathrm{C}$-malonyl $\mathrm{CoA}$ into fatty acids in the cell-free extracts of $X$. oryzae cell-free extracts, and possibly 2-mercaptoethanol is required as a protector of sulfhydryl-enzymes. However, either factor of CoA or 2-mercaptoethanol was not introduced into the mixture in oder to avoid a bare possibility of the binding of the two to NaDMDC.

Effect of NaDMDC on the fatty acid synthesis in $X$. oryzae cell free extracts

As illustrated in Fig. 1, by the use of the reaction mixture of $X$. oryzae cell-free extracts noted above, the incorporation of ${ }^{14} \mathrm{C}$-malonyl $\mathrm{CoA}$ into fatty acids increased with the lapse of time during $30 \mathrm{~min}$. When NaDMDC was added to the reaction mixture, the radioactivity of ${ }^{4} \mathrm{C}$-malonyl CoA incorporated into fatty acids remarkably diminished, and the inhibition of the incorpo- 
ration by NaDMDC was about $50 \%$ at a concentration of $10 \mu \mathrm{g} / \mathrm{ml}$ and more than 70 $\%$ at $100 \mu \mathrm{g} / \mathrm{ml}$. Such a high inhibition of fatty acid synthesis by NaDMDC is correspondent with the result obtained in the fatty acid synthase system of $E$. coli. The results lead to a conclusion that the primary action of NaDMDC is involved in the fatty acid biosynthesis of $X$. oryzae.

\section{Discussion}

Although a significant knowlege for understanding the outline of the lipid biosynthesis of bacteria has been given by investigations in some bacteria, especially in $E$. coli, there is no information about the mechanism of lipid biosynthesis in $X$. oryzae. In gram-negative bacteria a large portion of their cellular lipids is composed of glycerophospholipids, and the biosynthesis of glycerophospholipids requires two precursors: glycerol-3-phosphate derived from dihydroxyacetone phosphate generating during glycolysis and fatty acyl ACP produced by successive addition of the two carbon atoms of malonyl ACP to acetyl ACP. As shown in Fig. 2, the first stage

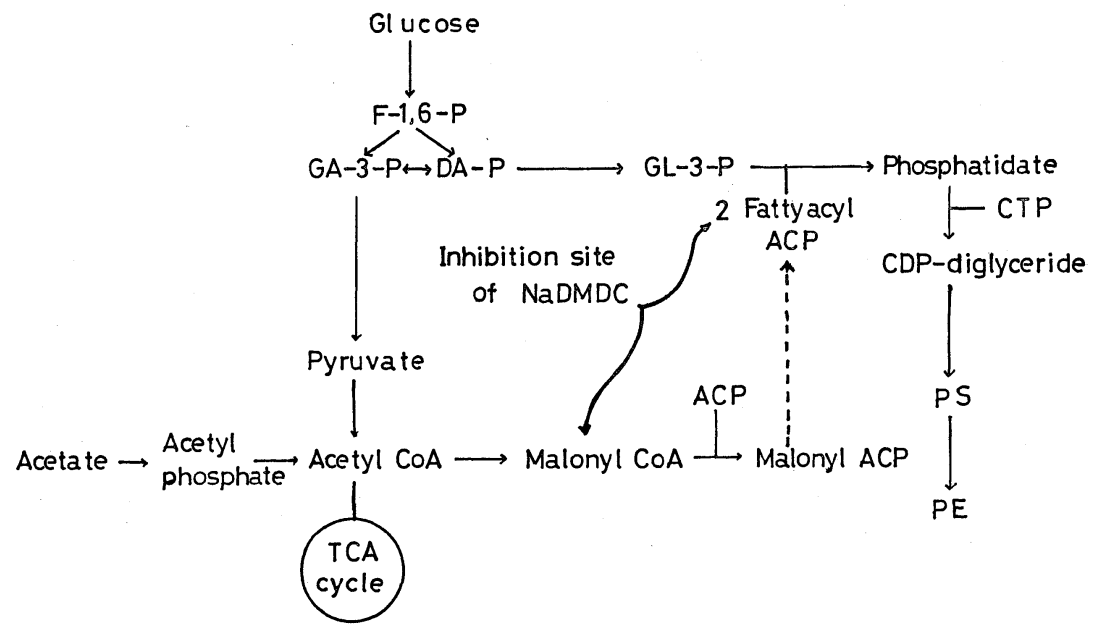

Fig. 2. Schematic representation of phospholipid biosynthesis

in glycerophospholipid formation is the acylation of glycerol phosphate by two molecules of fatty acyl ACP to yield a phosphatidic acid, and all glycerophospholipids are formed by a branching biosynthetic pathway starting from phosphatidic acid. This pathway is useful to investigate the mechanism of inhibition of lipid synthesis by NaDMDC. Since NaDMDC did not inhibit the incorporation of isotopic long-chain fatty acids ( ${ }^{14} \mathrm{C}$-palmitic acid, ${ }^{14} \mathrm{C}$-oleic acid) into the phospholipids of $X$. oryzae ${ }^{23)}$, it is clear that NaDMDC inhibits neither the synthetic process from phosphatidic acid to the other phospholipids nor the transfer step of long-chain fatty acids to glycerol phosphate. Thus, the inhibition of lipid synthesis by NaDMDC appeared to be involved in the synthetic process from acetate to fatty acid formation. This paper described the effects of NaDMDC on the fatty acid formation.

The formation of acetyl CoA from acetate, which is catalyzed by two enzymes such as acetate kinase and phosphotransacetylase, was not inhibited by NaDMDC. This result is also convinced by the fact that NaDMDC scarcely inhibits the oxidation of acetate in the exogeneous respiration of $X$. oryzae ${ }^{22)}$. However, Owens and Rubinstein ${ }^{13)}$ reported that CoA reacted readily with thiram, a compound in which two molecules of dimethyldithiocarbamate (DMDC) are linked by their sulfhydryl 
groups. The mechanism of action of NaDMDC and that of thiram seem to be different, since acetyl CoA formation was not interfered with NaDMDC. Also, acetyl CoA carboxylase from $E$. coli, an enzyme which catalyzes the synthesis of malonyl CoA from acetyl CoA, was not inactivated by NaDMDC, which indicates that NaDMDC does not inhibit malonyl CoA formation in fatty acid synthetic process. On the other hand, the incorporation of ${ }^{14} \mathrm{C}$-malonyl CoA into fatty acids was markedly inhibited by NaDMDC in either $E$. coli enzyme system or $X$. oryzae cell-free extracts. These evidences show that NaDMDC inhibits primarily the fatty acid synthesis of $X$. oryzae, and affects the entire lipid biosynthesis in the bacterium. Among the enzymes concerned with fatty acid biosynthesis in bacteria, many kinds of sulfhydryl-containing enzymes are known to be inhibited by alkylating agents. Such enzymes are acetyl CoA transacylase ${ }^{21)}$, malonyl CoA transacylase ${ }^{21)}, \beta$-ketoacyl ACP synthetase ${ }^{1)}$, enoyl ACP reductase ${ }^{20}$ ) and so on. Thus, inhibition of fatty acid synthesis by NaDMDC is probably resulted from inactivating some of these enzymes, because NaDMDC is able to react readily with sulfhydryl-compounds. As for agricultural fungicides, there seems to be no other study than the one by Tweedy and Turner, who reported that the fatty acid content in the spores of Monilia furucticola rapidly decreased when treated with sulfur agent. Sulfur agent also may be an inhibitor of fatty acid synthesis as well as NaDMDC.

In the investigations concerning the mode of action of NaDMDC, an important point to be considered is about the biological conversion of NaDMDC to the other derivatives. Ludwig and Thorn ${ }^{10)}$, Keilin and Hartree ${ }^{7)}$ and Richardson and Thorn ${ }^{14}$ ) pointed out the interconversion of DMDC and thiram in living cells. On the other hand, Owens and Rubinstein ${ }^{13}$ ) suggested that the oxidation of DMDC to thiram did not proceed quantatively enough to demonstrate the action of thiram in the cells. Since living cells have a large number of the oxidation-reduction systems connected with the metabolism of substances, it is likely that the metabolic inhibition by NaDMDC is possibly caused by the cooperation of DMDC and thiram. Therefore, the problem still remains to elucidate more fully the mechanism of action of thiram, in special relation to its effect on fatty acid synthesis. There exists another problem related to the site within the cells attacked by NaDMDC. In fungal cells, the site of fatty acid synthesis is in mitochondria, and in bacterial cells it is located in cell menbrane. The difference will naturally cause a difference in the site where the compound reaches and therefore in its effect on the cells. This point shoud also be examined further to understand the mechanism of action of dithiocarbamates.

The authors are grateful to Dr. K. Ko of our laboratory for his valuable advice during the progress of the investigation.

\section{Literature cited}

1) Alberts, A. W., Majerus, P. W. and Vagelos, P. R. (1965). Biochemistry $4: 2265-2274$.

2) Alberts, A. W. and Vagelos, P. R. (1968). Pro. Nat. Acad. Sci. $59: 561-568$.

3) Goks $\phi$ yr, J. (1955). Physiol. Plantarum $8: 719-835$.

4) Goldman, P., Alberts, A. W. and Vagelos, P. R. (1963). J. Biol. Chem. $238:$ 1255-1261.

5) Gornall, A. G., Bardawill, C. J. and David, M. M. (1949). ibid $177: 751-766$.

6) Hsu, R. Y., Wassen, G. and Porter, J. W. (1965). ibid $240: 3736-3746$.

7) Keilin, D. and Hartree, E. F. (1940). Pro. Roy. Soc. B $129: 277-306$.

8) Lipmann, F. and Tuttle, L. C. (1945). J. Biol. Chem. $158: 505-519$.

9) Lowry, O. H., Rosebrough, N. J., Farr, A. L. and Randall, R. J. (1951). ibid 193: 265-275.

10) Ludwig, R. A. and Thorn, G. D. (1960). Advan. Pest Control Res. 3. (Metcalf, R L. ed.). Interscience Pub. New York, pp. 219-252.

11) Owens, R. G. (1953). Contrib. Boyce Thompson Inst. $17: 221-242$. 
12) Owens, R. G. (1963). Ann. Rev. Phytopath. $1: 77-100$.

13) Owens, R. G. and Rubinstein, J. H. (1964). Contrib. Boyce Thompson Inst. 22 : 241-257.

14) Richardson, L. T. and Thorn, G. D. (1961). Can. J. Botany $39: 531-540$.

15) Rose, I. A. (1955). Methods in Enzymology I. pp. 591-595.

16) Sisler, H. D. and Cox, C. E. (1955). Am. J. Botany $42: 351-356$.

17) Stadtman, E. R., Novelli, G. D. and Lipmann, F. C. (1951). J. Biol. Chem. $191: 365-376$.

18) Suwa, T. (1962). Ann. Phytopathol. Soc. Japan $27: 165-171$.

19) Tweedy, B. G. and Turner, N. (1966). Contrib. Boyce Thompson Inst. $23: 235-242$.

20) Weeks, G. and Wakil, S. J. (1968). J. Biol. Chem. $243: 1180-1189$.

21) Williamson, I. P. and Wakil, S. J. (1966), ibid $241: 2326-2332$.

22) Yoneyama, K. and Misato, T. (1971). Ann. Phytopathol. Soc. Japan $37: 291-300$.

23) Yoneyama, K. and Misato, T. (1978). ibid $44: 305-312$.

\title{
Dithiocarbamate 系殺菌剂の作用機作に関する研究 3 . イネ白葉枯病 菌の脂肪酸合成に及ぼす sodium dimethyldithiocarbamate の作用
}

\author{
米山 勝美・関戸茂子・見里 朝 正
}

Sodium dimethyldithiocarbamate (NaDMDC) の作用機作に関する以前の研究は,イネ白葉枯病菌の 脂質合成阻害が長鎖脂肪酸からリン脂質合成までの過程に関連しないととを明らかにした。本研㕤では酶酸 から脂肪酸形成までの過程に及ぼす NaDMDC の作用について調べた。

1. NaDMDC は酰酸加ら acetyl CoA 亿関与する 2 種の酵素 acetate kinase, phosphotransacetylase のどちらにあ阻害作用を有しなかった。

2. acetyl CoA から malonyl CoA 合成に関与する酵素 acetyl CoA carboxylase 亿対しても NaDMDC は阻害を示さなかった。

3. 白葉枯病菌の無細胞抽出液あるいは大腸菌の脂肪酸合成酵素系にお打る脂肪酸への ${ }^{14} \mathrm{C}$-malonyl CoA の取り込みは NaDMDC によって顕著に阻害された。

以上の結果から，NaDMDC は白葉枯病菌の脂肪酸合成を第一次的に阻害し，脂質合成全体に著しい影響 を与えるものと考えられる。 